\title{
The nutritional toxicity of Phaseolus vulgaris lectins
}

\author{
By A. Pusztai, Eileen M. W. Clarke and T. P. King, The Rowett Research \\ Institute, Bucksburn, Aberdeen $A B 29 S B$
}

The early indications (for a review see Jaffé, 1969) that the nutritional toxicity of kidney beans (Phaseolus vulgaris) is, at least partly, due to the presence of high concentrations of lectins in these seeds, have now been confirmed by the isolation of pure lectins and their nutritional testing. Thus, a lectin component isolated from navy (haricot) bean (Andrews, 1974) was found to be toxic for Japanese quail (Jayne-Williams \& Burgess, 1974). Similarly, a correlation was found between lectin content in white kidney bean (cv. 'Processor') and the extent of depression of protein utilization for the rat (Pusztai et al. 1975). The dependence of NPUdepression by pure lectins in a $5 \%$ casein-containing diet obeyed the following formula (Pusztai \& Palmer, 1977): NPU $=\mathrm{NPU}_{5} \%$ casein $-280 x$ (where $x$ is the lectin content in the diet as per cent $w / w)$.

It has been suggested that the ingested lectin might exert its toxic effects on the recipient animals by interfering with their digestion and/or absorption (Jaffé \& Vega Lette, I968), by the formation of intestinal and other lesions (Tedeschi et al. 1965) or by an impairment of body defences and the consequent tissue invasion by normally innocuous gut bacteria (Jayne-Williams \& Burgess, 1974). In the present paper these and other potentially feasible mechanisms of lectin action on animals will be described and discussed in the light of fresh experimental evidence.

\section{Morphological studies}

Light microscopy. Many of the brush borders of duodenal and jejunal enterocytes were severely disrupted in rats fed on diets containing 'Processor' beans or purified lectins (Plate Ia). The disruption was largely confined to enterocytes located on the upper half or two-thirds of duodenal and jejunal villi. The brush borders in rats fed on diets containing low-lectin 'Pinto III' beans or control diets were not damaged (Plate $\mathrm{Ib}$ ). The occurrence of the brush border lesion is summarized in Table $\mathrm{I}$.

An apparent overgrowth of bacteria occurred in the small intestines of rats fed on diets containing 'Processor' beans. In contrast, the number of bacteria associated with the disrupted brush borders of rats given purified lectin-containing diets or with the normal microvilli of rats fed on diets containing 'Pinto III' beans was much reduced.

Disruption of the brush border was evident in duodenum samples taken $\mathrm{I} h$ after rats had been given ground 'Processor' beans by stomach tube. The lesion became noticeable in jejunum samples approximately $0.5 \mathrm{~h}$ later. Bacteria, in these early samples, were not associated with the damaged brush borders. $8 \mathrm{~h}$ after feeding 
Table $\mathrm{I}$. Phaseolus vulgaris lectin-induced disruption of duodenal and jejunal enterocyte brush borders observed on 30-d-old rats fed on various diets for 10 d

\begin{tabular}{|c|c|c|c|}
\hline \multirow[b]{2}{*}{ Diet } & \multicolumn{2}{|c|}{$\begin{array}{l}\text { Protein source } \\
\text { ( } \% \text { protein in diet) }\end{array}$} & \multirow[b]{2}{*}{$\begin{array}{c}\text { Appearance of } \\
\text { brush border }\end{array}$} \\
\hline & Casein & $\begin{array}{l}\text { Bean } \\
\text { protein }\end{array}$ & \\
\hline $\begin{array}{l}\text { 'Processor' bean } \\
\text { 'Processor' globulin lectin } \\
\text { 'Processor' albumin lectin } \\
\text { 'Processor' low-lectin globulin }\end{array}$ & $\begin{array}{l}5 \\
5 \\
5\end{array}$ & $\begin{array}{l}5 \\
0.1 \\
0.2\end{array}$ & $\begin{array}{l}\text { Disrupted } \\
\text { Disrupted } \\
\text { Disrupted }\end{array}$ \\
\hline $\begin{array}{l}\text { fraction } \\
\text { Casein control } \\
\text { Pinto III bean (low-lectin) } \\
\text { Pinto III bean (low-lectin) } \\
\text { Non-protein control }\end{array}$ & $\frac{5}{5}$ & $\begin{array}{l}0.5 \\
\frac{1}{10} \\
5\end{array}$ & $\begin{array}{l}\text { Normal } \\
\text { Normal } \\
\text { Normal } \\
\text { Normal } \\
\text { Normal }\end{array}$ \\
\hline
\end{tabular}

and in the absence of further feeding with beans or lectins, the extent of the lesion was much reduced, cell migration having effected the replacement of many of the lectin-damaged cells. Brush borders in the ileum remained normal.

Electron microscopy. Irregularly arranged, stunted, elongated, fragmented or vesiculated microvilli were present on the apical surfaces of duodenal and jejunal enterocytes in rats fed on diets containing 'Processor' beans or purified bean lectins (Plate Ic). Vesiculated membranous debris, flocculent electron-dense material, goblet cell mucins and coliform bacteria were often associated with the disrupted microvilli. Changes within the enterocytes also accompanied the damage to the microvilli. A detailed description and the full implications of these fine structural studies on lectin-induced cellular and other changes are, however, beyond the scope of the present paper and these will be published elsewhere.

\section{Balance studies}

Inclusion of beans in a $5 \%$ casein-containing diet depressed appetite, growth and NPU (Palmer et al. 1973). With increasing amounts of beans in the diet the amount of absorbed dry matter also decreased (Table 2). However, even in the worst case, over $83 \%$ of the dry matter was apparently absorbed by the rat (Table 2). Under these conditions although the proportion of the absorbed protein was less than $60 \%$ of that ingested, the total amount of protein absorbed from the various diets was constant, irrespective of the different protein content in the diets. Despite this, in bean-fed rats growth was depressed and the NPU, which was 61 in the absence of beans, fell to near zero in the presence of $5 \%$ bean protein in the diet. The reason for this may be found from the results of $\mathbf{N}$ balance experiments. Thus, rats fed on a $10 \%$ casein-containing diet excreted an equivalent of about $10 \%$ of the ingested $\mathrm{N}$ in the urine. Similarly, when $5 \%$ casein was given together with $5 \%$ 'Pinto III' (low-lectin) beans, this proportion was about the same, about I $1 \%$. The absolute amount of $N$ excreted in both instances was fairly similar to that found in the urine of the non-protein control rats. The inclusion of $5 \%$ of the high- 
Table 2. Quantitative results obtained from rat NPU experiments. Amounts of food eaten and faeces excreted are those obtained during the last $6 d$ of the ro $d$ experimental period. NPU values are calculated from nitrogen determinations on the rat carcass

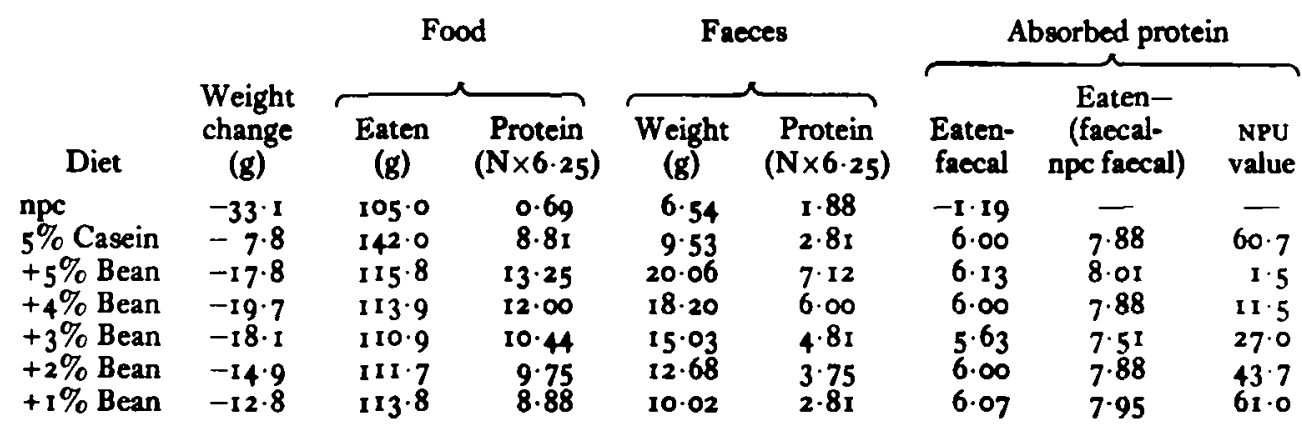

lectin 'Processor' bean in the diet, however, raised the urinary $\mathrm{N}$ output to an equivalent of over half of that ingested. Thus, although the bean-fed rats might absorb a similar amount of $\mathrm{N}$ from the diet as those on casein, in the presence of lectins the combined $\mathbf{N}$ content of urine and faeces could exceed that ingested and put the rat into negative $\mathrm{N}$ balance.

Next, rats were fed on a diet containing $5 \%$ casein plus $5 \%$ bean protein for $5 \mathrm{~d}$, then switched to $10 \%$ casein for the next $5 \mathrm{~d}$, after which they were put back onto the bean diet for another $5 \mathrm{~d}$. These cycles were repeated and the progress of these rats was compared with that of pair-fed ro\% casein controls (Fig. 1.). Despite consuming similar amounts of food, the weight of the two groups became increasingly different with the progress of the experiment. In fact, this difference ought to have been larger as the control rats were very excited and used up a lot of energy seeking food, whilst the bean-fed rats remained depressed and inactive. The results of our preliminary experiments in the calorimeter, carried out in collaboration with Dr J. D. Pullar, appear to confirm this. In the presence of lectins the rats were thus apparently either less able to utilize absorbed food $\mathbf{N}$ or had an elevated protein catabolism. The net result, however, should be the same; an inability to grow and develop properly without an adequate supply of $\mathbf{N}$ for new protein synthesis. The results also showed that the effects of lectins in the diet were quickly established and were just as damaging at the end as at the beginning of the experiment (Fig. I.). Thus, no long-term protection against toxicity was observed. When switched to the casein diet, the rats recovered within $24 \mathrm{~h}$. It appears that as absorption of food was still appreciable in rats with wellestablished lectin-induced intestinal lesions, when the protein in the diet was changed for the non-toxic casein, the absorbed $\mathrm{N}$ was quickly and properly utilized with a consequent fast recovery for the animal. This was undoubtedly aided by the already demonstrated relatively fast (about $8 \mathrm{~h}$ ) replacement of the topmost damaged cells of the villi. 


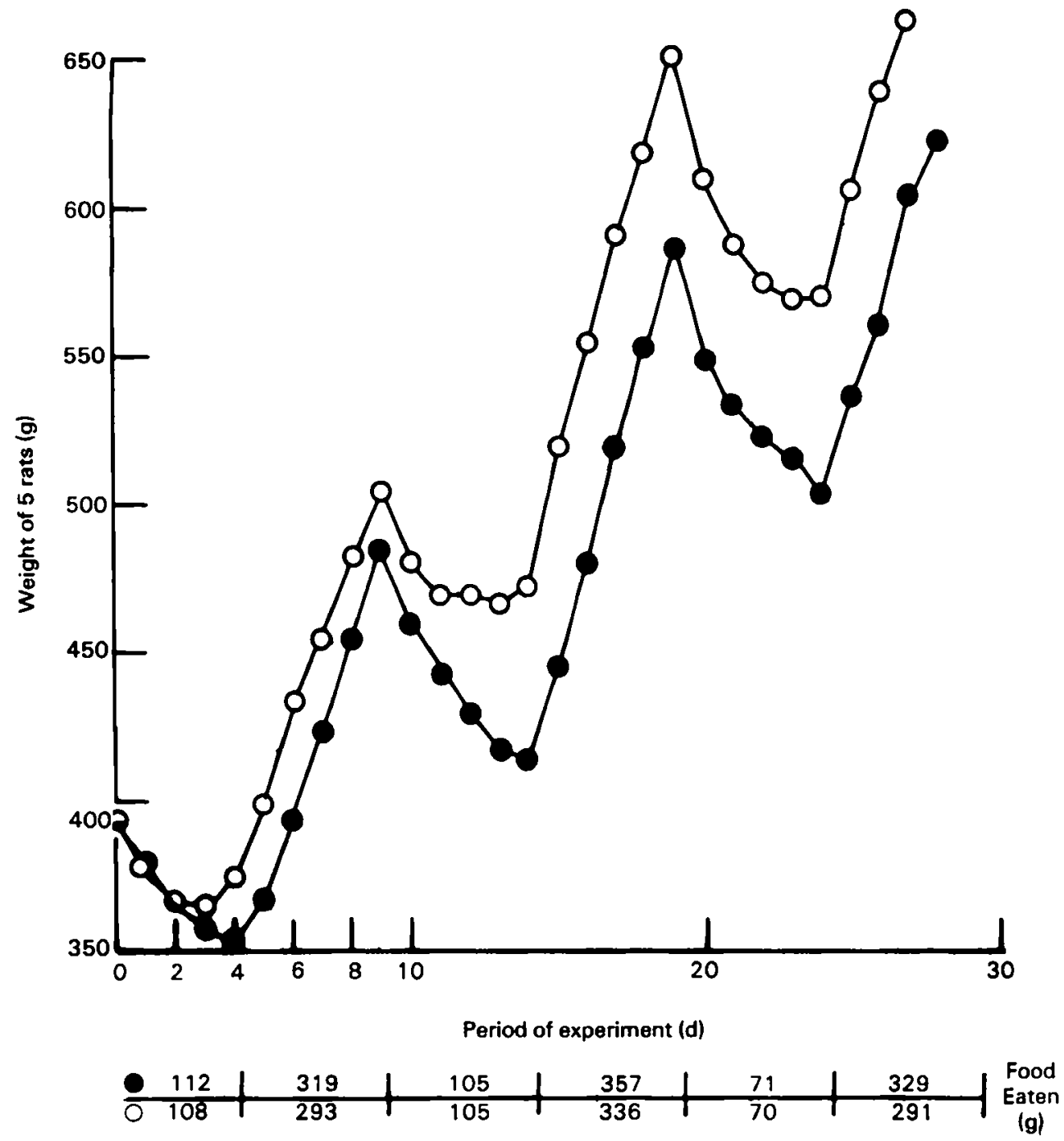

Fig. 1. Growth curve for pair-fed rats. The test rats $(-0)$ were fed for $5 \mathrm{~d}$ periods alternately on $5 \%$ bean plus $5 \%$ casein- and $10 \%$ casein-containing diets. Food intake of the control $10 \%$ casein-fed rats $(\mathrm{O}-\mathrm{O})$ was restricted to the amount of food eaten daily by the test rats. Six $5 \mathrm{~d}$ cycles were carried out and the weight of the rats was recorded daily.

\section{Immunochemical studies}

At the light microscope level, lectin tracer studies were performed on sections of the intestine using indirect immunofluorescence and peroxidase-antiperoxidase (PAP) techniques (Sternberger, 1974) in which the primary antiserum was monospecific for Phaseolus vulgaris globulin lectins. For the electron microscope 
pre- and post-embedding staining was performed using the PAP method (Sternberger, 1974).

Globulin lectin was detected on the disrupted brush borders of enterocytes in rats fed diets containing 'Processor' beans and purified globulin lectins (Plate Id). At the electron microscope level the flocculent material associated with the damaged microvilli stained positively for globulin lectin. It was shown previously (Pusztai, et al. 1975) that Phaseolus vulgaris lectins were resistant to in vitro proteolysis. The results of these immunocytochemical studies confirmed this in vivo by demonstrating a reaction of apparently intact lectins with the apical surfaces of enterocytes. Recent observations also indicated a similar resistance to proteolysis for wheat germ lectin (Brady et al. 1978). Lectins are known to have a great variety of profound effects on cells in vitro, including agglutination, induction of mitosis, interference with general metabolism (Sharon \& Lis, 1972; Pusztai \& Watt, 1974), impairment of membrane transport systems (Li \& Kornfeld, 1977) or increased membrane permeability for intracellular proteins (Moser et al. 1978). It may be speculated that the Phaseolus vulgaris lectins bound by the enterocytes might interfere with the normal metabolism and functions of these cells and thus cause the severe lesion observed by morphological studies on bean-fed rats. Damage to the microvilli is usually thought to restrict the absorption of nutrients from the small intestine. However, rats with severe lesions, when fed on a diet containing $5 \%$ bean protein, could still absorb over $83 \%$ of the food ingested (Table 2). While it was possible that some $\mathrm{N}$ might be absorbed from the hind gut as the result of bacterial fermentation, the demonstration that bean diets were not toxic for gnotobiotic rats (Rattray et al. 1974 ) indicated that such a process might not generally make appreciable contributions to food absorption in the rat. It appears therefore, that a large part of the ingested food could be absorbed in the small intestine, possibly through cells which had been little or not at all disrupted by the lectin. In addition, as a result of an increased membrane permeability in those cells which had reacted with the lectin, abnormal amounts of ions, nutrients, partially digested, modified or even intact and potentially toxic substances might also be absorbed. The results of preliminary immunochemical and immunocytochemical studies on bean-fed rats indicated that the lectin, itself a potentially harmful substance, was internalized by enterocytes and was also taken into the blood circulatory system. However, as neither long-term bean feeding nor the production of high-titre circulating anti-lectin antibodies by a course of subcutaneous injections of pure lectin into rats before the start of bean feeding could protect the animals from the effects of toxicity, it was thought unlikely that the observed toxicity was caused simply by the appearance of lectins in the blood. These results, when taken together with the previous observation that gnotobiotic rats were less affected by lectin-containing diets (Rattray et al. 1974), indicated that the lectin-induced intestinal lesions were but a first, though essential, step in the establishment of the toxicity. It is possible that as the result of an abnormal absorption through the damaged intestinal cells of potentially harmful substances, including lectins or other components of the diet, possibly modified in the gut by 
bacteria or by tissue enzymes or bacterial toxins, ensuing systemic effects, like an abnormally high rate of tissue protein catabolism, make it impossible for the rats to develop properly and remain healthy.

\section{Summary}

In rats fed on beans (Phaseolus vulgaris) the poorly digestible lectins were shown to react with intestinal cells in vivo and to cause a disruption of many of the brush borders of duodenal and jejunal enterocytes. Although depressed to a certain extent, absorption still occurred, probably through the non-disrupted cells of the small intestine. In addition, abnormal absorption of potentially harmful substances, lectin-related or of bacterial origin, could also occur, possibly as a direct effect of the disruption caused by the lectins on the enterocytes. It is suggested that toxicity was the result of ensuing systemic effects, such as for example the observed high $\mathrm{N}$ excretion possibly through increased tissue catabolism.

\section{REFERENCES}

Andrews, A. T. (1974). Biochem. f. 139, 42 I.

Brady, P. G., Vannier, A. M. \& Banwell, J. G. (1978). Gastroenterology, 75, 236.

Jaffe, W. G. (1969). In Toxic Constituents of Plant Foodstuffs, p. 69, [I. E. Liener, editor]. New York and London: Academic Press.

Jaffé, W. G. \& Vega Lette, C. L. (1968). F. Nutr. 94, 203.

Jayne-Williams, D. J. \& Burgess, C. D. (1974). F. appl. Bact. 37, 149.

Li, E. \& Kornfeld, S. (1977). Biochim. biophys. Acta, 469, 202.

Moser, H., Schneider, D. \& Falke D. (1978). Biochim. biophys. Acta, 507, 445.

Palmer, R., McIntosh, A. \& Pusztai, A. (1973). F. Sci. Fd agric. 24, 937.

Pusztai, A., Grant, G. \& Palmer, R. (1975). J. Sci. Fd agric. 26, 149.

Pusztai, A. \& Palmer, R. (1977). F. Sci. Fd agric. 28, 620.

Pusztai, A. \& Watt, W. B. (I974). Biochim. biophys. Acta, 365, 57.

Rattray, E. A. S., Palmer, R. \& Pusztai, A. (1974). F. Sci. Fd agric. 25, 1035.

Sharon, N. \& Lis, H. (1972). Science, 177, 949.

Sternberger, L. A. (1974). In Immunochemistry, p. 18, 129. Englewood-Cliffs, New Jersey: Prentice-Hall.

Tedeschi, G. G., Petrelli, F. \& Amici, D. (1965). Italian F. Biochem. 14, 237. 


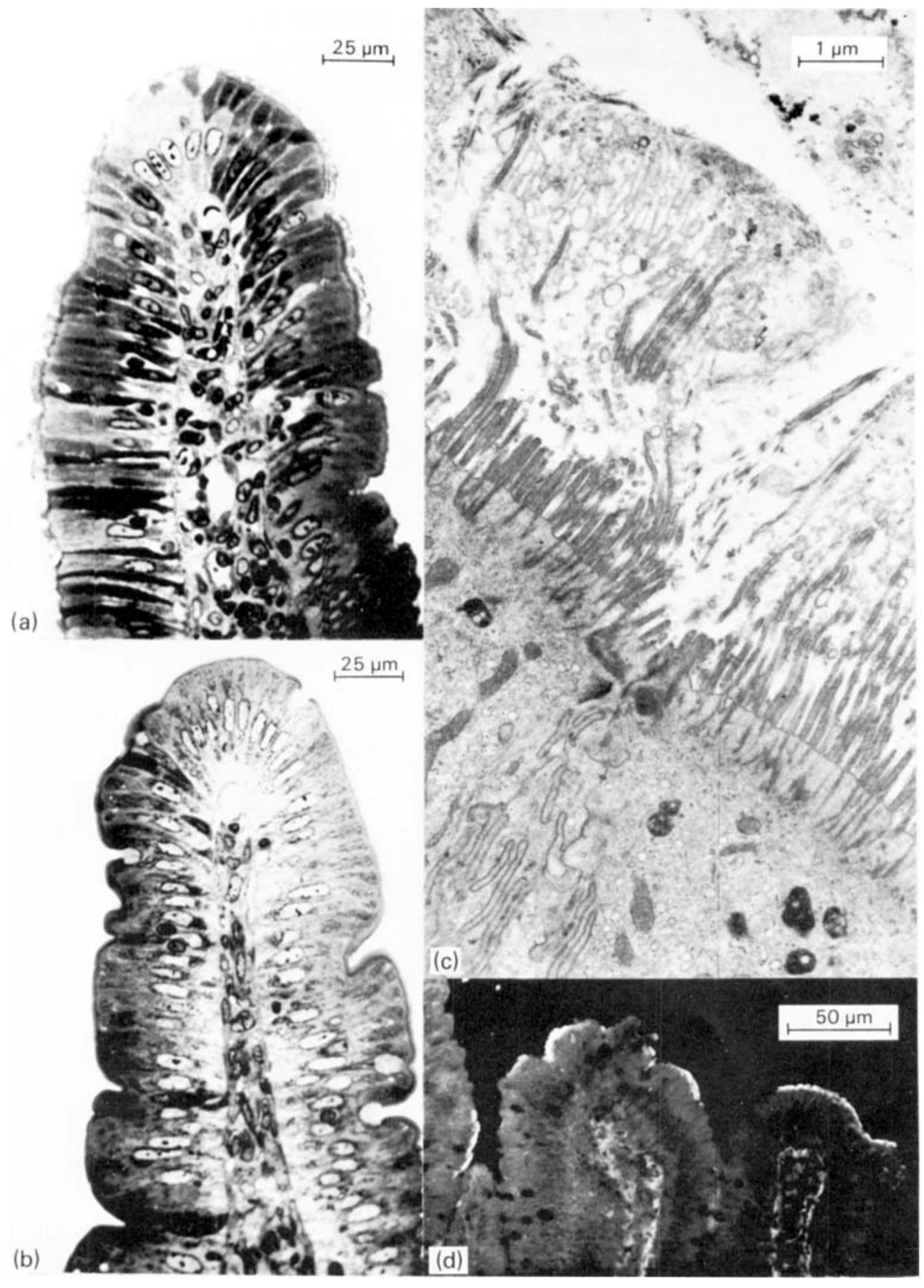

Plate I. (a) Part of a section through a duodenal villus taken $4 \mathrm{~h}$ after a rat had been given $280 \mathrm{mg}$ ground 'Processor' bean by stomach tube, showing disruption of the brush border. (b) Part of a section through a dundenal villus from a rat which had been fed a casein control diet, showing the normal brush border. (c) Electron micrograph showing disruption of the microvilli on duodenal enterocytes from a rat fed a diet containing $5 \%$ 'Processor' beans. (d) Immunofluorescence staining of 'Processor' bean lectin, showing reaction product on the disrupted brush border.

(facing page 120) 